\title{
1 The impacts of shrimp farming on land-use and carbon storage around 2 Puttalam Lagoon, Sri Lanka
}

3 Bournazel Jil ${ }^{\mathrm{a} 1}$, Marappullige Priyantha Kumara ${ }^{\mathrm{b}}$, Jayatissa Loku Pulukuttige ${ }^{\mathrm{c}}$, Viergever

4 Karin $^{\mathrm{d}}$, Morel Véronique ${ }^{\mathrm{d}}$ and Huxham Mark ${ }^{\text {ae }}$

5

6 a School of Life, Sport and Social Sciences, Edinburgh Napier University, Sighthill Court, 7 Edinburgh, EH11 4BN, United Kingdom, Tel: +44 (0)745 6036236; email:

8 jil.bournazel@gmail.com (Corresponding author)

9 bocean University, Mahawela Road, Tangalle, Sri Lanka. Tel: +94 (0)71 6035682; email: 10 kumarampp@yahoo.com

11 'Department of Botany, University of Ruhuna, Wellamadama, Matara, Sri Lanka. Tel: +94 12 (0)71 446 9527; email: lpj@bot.ruh.ac.lk

13 Ecometrica, Orchard Brae House, 30 Queensferry Road, Edinburgh, EH4 2HS, United

14 Kingdom. Tel: +44 (0) 131662 4342; email: Karin.viergever@ecometrica.com;

15 veronique.morel@ecometrica.com

16

17

eTel: +44 (0)131 2514; email: M.huxham@ @apier.ac.uk

18

19

20

21

22

23

24

25

26

27

28

29 
31 Abstract

32 The expansion of shrimp aquaculture in Sri Lanka over the past three decades has dramatically changed the coastal landscape, in particular by converting mangrove forests.

34 The current study quantified these impacts in the Puttalam lagoon, an area of the country that 35 has experienced some of the most destructive development. Land use change was analysed 36 using a multi-temporal set of aerial and satellite images taken in 1992/1994 (aerial 37 photographs), 2007 (SPOT 5) and 2012 (Pleiades). The area of shrimp farms increased by 2 $38777 \%$ over this 19 -year period, with salt pans expanding by $60 \%$. Mangroves declined in area by $34 \%$ and coconut groves increased by $17 \%$. Because of problems with disease many intensive shrimp farms are abandoned after a few years, leaving denuded and unproductive landscapes; here a large majority of farms (90\% of the total area of shrimp aquaculture) were found to be abandoned. The loss of carbon sequestration and storage services caused by this unsustainable recent history of shrimp farming was calculated as one measure of environmental impact. The documented land use changes in Puttalam lagoon resulted in an estimated net carbon loss of $191584 \mathrm{tC}$. This was mainly due to conversion of mangroves to shrimp farms, making up $75.5 \%$ of the total carbon loss. These results demonstrate the scale of environmental degradation caused by intensive shrimp farming in the study area, and highlight the need for an entirely new aquaculture model in Sri Lanka.

Keywords: shrimp aquaculture; ecosystem carbon stock changes; land-cover changes; 50 mangrove; Sri-Lanka 


\section{Introduction}

Although shrimp production in coastal pond systems is a traditional practice in Asia (Dierberg and Kiattsimkul, 1996; Bergquist, 2007), recent decades have seen a huge increase in the extent and intensity of shrimp aquaculture activities, driven by consumer demand from Japan, North America and Europe (Primavera, 1997; Thornton et al., 2003; Bergquist, 2007; Bosma and Verdegem 2011). Sri Lankan shrimp farming became one of the fastest growing industries in the 1980s, most likely inspired by the profits seen in established shrimp farming practices in countries such as Thailand, Ecuador, Indonesia, China and Vietnam (Cattermoul and Devendra, 2002; Munasinghe et al., 2010).

Sri Lanka has $1700 \mathrm{~km}$ of coastline comprising lagoons and sheltered bays that are prime sites for aquaculture development (Dayananda, 2004; Drengstig, 2013). Shrimp farming started in the north western coast of the country, with pioneer farms established around Chilaw Lake (Fig.1; Senerath and Visvanathan, 2001), which were followed by rapid expansion particularly concentrated along the coast from Chilaw to Puttalam lagoon in the northwestern province (NWP) (Dahdouh-Guebas et al., 2001; Munasinghe et al., 2010).

The major shrimp species cultured in Sri Lanka is Panaeus monodon (Fabricius), commonly known as black tiger shrimp, which is naturally found along the Sri Lankan coast (Cattermoul and Devendra, 2002). During its peak period, shrimp farming was an important source of employment in Sri Lanka and shrimp exports represented one of the main sources of foreign exchange for the country, accounting for $40-50 \%$ of total aquaculture exports (Senerath and Visvanathan, 2001; Dayananda, 2004; Munasinghe et al., 2010). Although there is significant potential for the industry to contribute to national economic growth and to reduce poverty, unsustainable shrimp culture causes environmental as well as socio-economic harm due to the exploitation of coastal natural resources (Bergquist, 2007; Rajitha et al., 2007). The major environmental impacts of unsustainable shrimp farming have been well documented. The main problems are caused by direct conversion of natural habitats to shrimp ponds, which leads to drastic loss of mangrove forests, salt marshes, seagrass beds and mudflats, along with many of their associated ecosystem services (Senerath and Visvanathan, 2001). Other environmental impacts are caused by the disposal of untreated wastewater, rich in nutrients and often laden with pesticides and antibiotics, directly into lagoon waters (EJF, 2004; Primavera, 2006). Furthermore, excessive use of antibiotics encourages the emergence of 
antibiotic-resistant strains whilst chemical discharges damage off-target populations and pollute aquifers (Primavera, 2006; Bosma and Verdegem 2011). Other environmental impacts may include declines in wild capture of fish and shrimp (Cattermoul and Devendra, 2002) and the spread of diseases such as the White Spot Syndrome Virus (WSSV), which is considered the most serious pathogen of shrimp, causing 100\% mortality within 7-10 days in infected shrimp farms (Witteveldt et al., 2004; Primavera, 2006). In the NWP of Sri Lanka, which includes Puttalam lagoon, the Dutch Canal is the main source of water for shrimp farms. This semi-enclosed coastal water system has a low flushing rate, which exacerbates these problems, with hydrological changes, salinization of soil and water and siltation now also recorded in the area (EJF, 2004; Weerakoon, 2007).

Because of disease and other problems, the productivity of intensive shrimp ponds often declines after 4-10 years. Ponds may then be abandoned and new areas cleared during the establishment of new ponds (Bosma and Verdegem, 2011). There are socio-economic as well as environmental costs of intensive shrimp cultivation. The poorest people on the coast are usually highly dependent on coastal ecosystems such as mangroves (Dayananda, 2004). In Thailand, it has been estimated that intact mangrove forests have a total economic value $70 \%$ higher than shrimp farms, largely because of the range of ecosystem services that are destroyed by conversion of mangroves to ponds (Primavera, 2006). The expansion of aquaculture despite these economic losses is testament to differences in power between those who benefit and lose rather than any economic logic. A pattern of rapid expansion followed by abandonment and local collapse of the industry, with resultant coastal unemployment, is a sadly familiar story (Primavera, 2006).

Extensive mangrove destruction leads to loss of goods and services for local populations including loss of coastal protection, decreased availability of timber and firewood and loss of breeding and nursery grounds for fish (Alongi, 2002; Satyanarayana et al., 2013). Mangroves provide important habitat for a wide range of species hence their removal also reduces local biodiversity (Pathirana et al., 2008). One of the most important regulating ecosystem services of mangroves is their ability to sequester carbon. In fact, they are amongst the most carbon dense of all ecosystems and are thus globally important carbon sinks (Alongi, 2012). If disturbed by land-use change, the carbon buried in mangroves has the potential to become a significant source of greenhouse gas (Donato et al., 2011). Carbon storage in mangroves is 
122 also a factor for economic opportunities. A recent study valued carbon sequestration in 123 southern Kenya to be 251 USD/ha, measured from 2014 estimates, which makes this 124 ecosystem service the $2^{\text {nd }}$ most valuable after protection against coastal erosion (Huxham et $a l .$, in press).

126 By providing a description of the actual shrimp farming situation and the coastal ecosystem 127 losses of services in Puttalam, this paper aimed to aid in the management and conservation of 128 mangroves as well as highlighted the need for more sustainable aquaculture practices around 129 the lagoon. There is indeed an important gap in Sri Lankan policies response to deforestation 130 as well as a need for stronger land use policies (Government of Sri Lanka, 2000; 131 Bandaratillake and Sarath Fernando, 2003). The current study had two objectives. First it 132 aimed to provide an up-to-date assessment of land-use changes driven by aquaculture in 133 Puttalam lagoon region during the period early 1990s to 2012. The second and final objective 134 of the current work was to assess the loss of carbon sequestration and storage ecosystem 135 services as one measure of environmental impacts of farm expansion in Puttalam.

136 Indeed, the latest available Sri Lankan national forest inventory dates from 1992-1996 137 (Mattsson et al., 2012). Recording the presence of aquaculture ponds does not reveal their 138 economic viability; all authors recognise that many ponds are permanently or temporarily 139 abandoned (Di Nitto et al., 2013). However, estimates of the degree of abandonment vary 140 widely. Hence this study also assessed the proportion of all ponds that are still productive, 141 which is essential information in considering the current state of the aquaculture industry in 142 Sri Lanka and how improvements can be made.

143 Finally, one of the key ecosystem services provided by mangroves is carbon sequestration 144 and storage. Removal of mangrove forests by shrimp farmers certainly causes the loss of 145 future sequestration potential and may lead to the partial or total loss of stored carbon. 146 However, there are no published reports on the impacts of shrimp ponds on carbon stores. A 147 final objective of the current work was therefore to assess the impacts of aquaculture in 148 Puttalam on the carbon balance of the landscape and to represent the spatial distribution of 149 carbon dynamics. 
151

152

153

154

155

156

157

158

159

160

161

162

163

164

165

166

167

168

169

170

171

172

173

174

175

176

177

178

179

180

\section{Methods}

\subsection{Study site}

This study was conducted in the Puttalam lagoon situated in the NWP of Sri Lanka (Fig. 1). The lagoon has a surface area of $32700 \mathrm{ha}$ and the surface temperature of the water ranges from $28{ }^{\circ} \mathrm{C}$ to $32{ }^{\circ} \mathrm{C}$ (Pathirana et al., 2008). The area is subject to a micro-tidal regime that limits the tides to within $1 \mathrm{~m}$ range. The Puttalam lagoon is connected to the open ocean through the Dutch Bay located at the northern end of the lagoon. Seasonal precipitation levels are driven by monsoon winds and show a bimodal pattern. The long rains fall between mid May and early October and the short and weaker rains fall from December to early March (Di Nitto et al., 2013). The population density in Puttalam was $431 / \mathrm{km}^{2}$ in 2010 (Ranasinghe, 2010) and most people in the area rely directly or indirectly on fisheries (Pathirana et al., 2008). The west of the lagoon consists of sand dunes and long sandy beaches, while the east and south are cultivated land and forest (Ranasinghe, 2010). Coconut plantations are the main agricultural crop grown around the lagoon, as well as some banana, cashew, vegetables and home garden areas. Shrimp ponds, salt pans and irrigation canals also commonly occur (Ranasinghe, 2010). This coastal area presents ideal characteristics for the installation of shrimp ponds such as protected coastal lagoons, easy access by road to and from the international airport of Colombo as well as being located away from zones of political conflict (Munasinghe et al., 2010). The shrimp farms in Puttalam are mainly small-scale, with 73\% of them covering an area of less than 2 ha (Munasinghe et al., 2010). A major proportion of the total extent of mangroves in Sri Lanka is found in the Puttalam lagoon area, especially in sheltered estuaries (Pernetta, 1993). These forests exhibit high floral diversity and thus belong to the most valued mangrove forests in Sri Lanka (Amarasinghe, 1988; Jayatissa et al., 2002; Ranasinghe, 2010). 


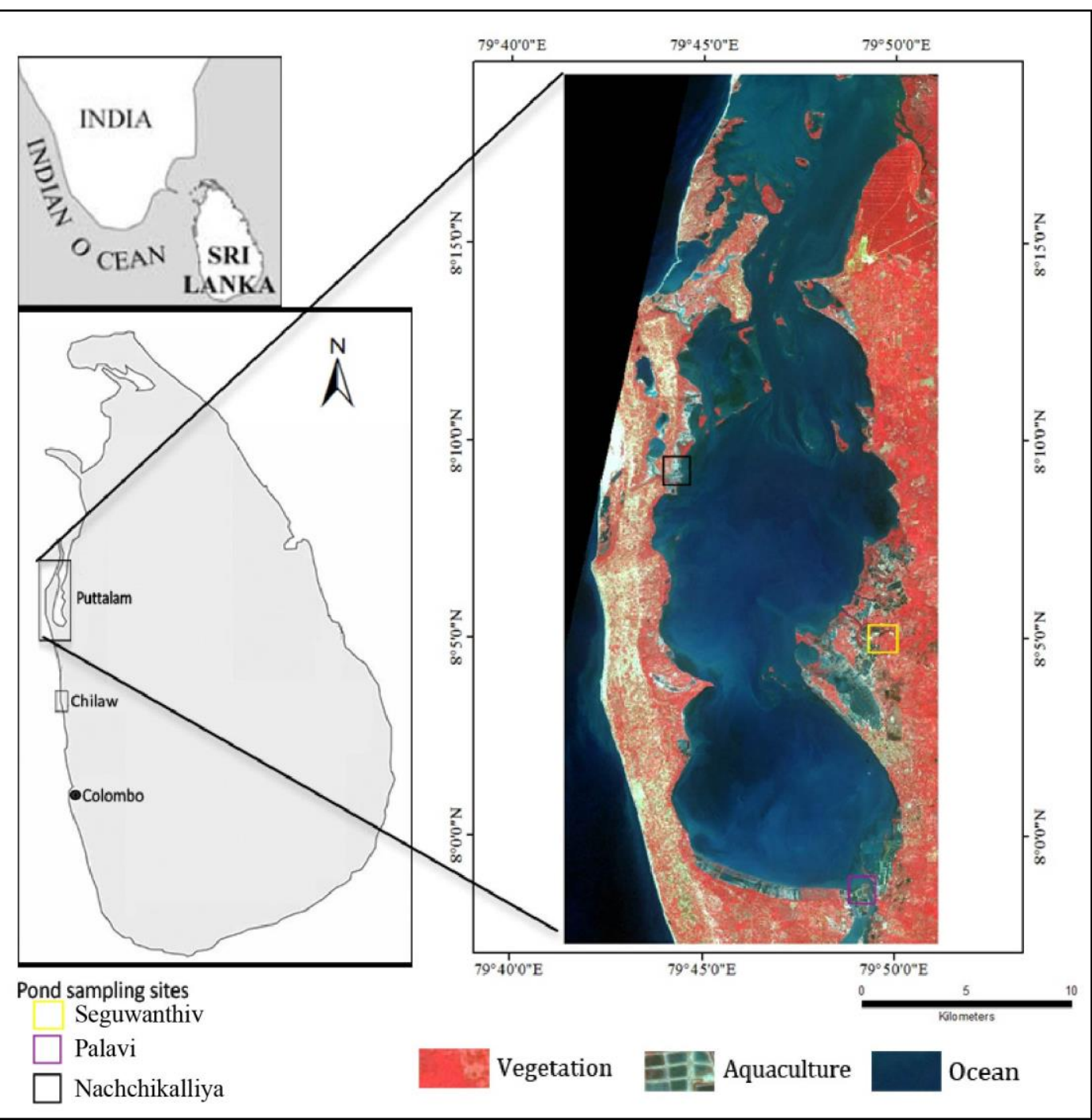

215 photographs, acquired between 1992 and 1994, covering Puttalam lagoon (Survey 216 Department of Sri Lanka).

217 The data set available for 2007 consisted of one SPOT 5 image covering the area of the 218 lagoon. SPOT 5 images have a spatial resolution of $10 \mathrm{~m}$ in multispectral mode.

219 Finally, two overlapping Pleiades images were available from 2012, with a high spatial 220 resolution of $50 \mathrm{~cm}$ and four bands (blue, green, red and NIR). 
221

222

223 The aerial photographs were geo-referenced using ArcGIS 9.3 (The Environmental Systems 224 Research Institute, USA) (UTM map projection: WGS_1984datum, UTM_Zone_44N),

\subsubsection{Images processing} resulting in an average root mean square error of $8.95 \mathrm{~m}$. They were then compiled together with the mosaic tool in ArcGIS.

Then the photographs and the SPOT 5 image were classified using an Object-Based Image Analysis (OBIA) within eCognition 8.7 (Definiens-Imaging, Germany). All scenes were featured in a UTM map projection (WGS_1984 datum, UTM_Zone_44N). The OBIA creates "objects" by segmenting an image into groups of pixels showing similar characteristics based on spectral properties such as spectral band or index (e.g. NDVI) means, and on spatial properties such as image texture.

The segmented object properties were then used for image classification (Robin et al., 2010; Heumann, 2011). Two multi-resolution segmentations were applied within eCognition software to the SPOT 5 image with the same weight for each of the three bands. The first segmentation (scale parameter $=30$, shape $=0.05$, compactness $=0.5$ ) was used to extract aquaculture ponds (shrimp farms and salt pans). As pond areas are clearly demarcated by dykes, they exhibit a good structure for segmentation. A second segmentation was performed in order to detect mangrove forest patches (scale parameter $=10$, shape $=0.05$, compactness=0.5). A multi-resolution segmentation was also applied to the aerial photographs (scale parameter $=50$, shape $=0.5$, compactness $=0.5$ ).

\subsubsection{Image classifications}

A visual classification of different land uses in Puttalam lagoon (four classes: shrimp farm, salt pan, mangrove, coconut plantation) was performed at the object level resulting from multi-resolution segmentation of the aerial photographs. The classification was based on visual analysis of the aerial photographs using features such as tonality or texture. Some areas of the lagoon could not be classified for 1992-1994 as photographs were not available, resulting in $4 \%$ of the study area not covered by these data. 
254 The classification of the SPOT 5 image was carried out following the multi-resolution 255 segmentation using the same land use classes mentioned above. The classes were derived within eCognition software using a decision tree (Fig. 2). When confusion between objects occurred, they were manually edited using visual interpretation and existing maps of the area when available.

Figure 2 OBIA decision tree (rectangle=image, diamond = rule, oval = class) used to classify the SPOT 5 image from 2007. * MRS = Muti-Resolution Segmentation, NDVI = Normalized Differerte 60 Vegetation Index, $Y=Y e s, N=N o$.

278 Finally, the Pleiades images from 2012 were also classified with the same use classes using

279 the Iso cluster tool within ArcGIS 10. The Maximum Likelihood Classification (MLC, in ArcGIS 10) was then applied to the image. MLC is an unsupervised classification based on an automated routine. The results were then refined manually to reduce error.

\subsubsection{Validation}

A total of 360 reference points were used within Google Earth images (Google Earth, 2011) to assess the accuracy of the land-use/cover classification produced for the 2012 data set. A confusion matrix with descriptive statistics (Table 1) was computed as per Carney et al. 
288 (2014). An overall classification accuracy of 79\% was achieved for the 2012 Puttalam lagoon 289 land-use/cover classification using the MLC method. The largest classification error occurred 290 for the class 'Other' (with 62\% accuracy, Table 1), while Coconut plantations was the most accurate class (92\% accuracy, Table 1). Accuracy of classifications from aerial photographs and SPOT5 image could not be assessed due to the lack of reference data at that time.

293 However, as the aerial photography classification was based on visual assessment and only 294 four classes were used, the chance of misclassification was minimised.

Table 1 The accuracy confusion matrix of Pleiade classification image.

\begin{tabular}{llllllll}
\hline Categories & Mangroves & $\begin{array}{l}\text { Shrimp } \\
\text { farms }\end{array}$ & Salt pans & $\begin{array}{l}\text { Coconut } \\
\text { plantations }\end{array}$ & Other & Total & $\begin{array}{l}\text { User's } \\
\text { accuracy }\end{array}$ \\
\hline Mangroves & $\mathbf{5 6}$ & 0 & 0 & 0 & 13 & 69 & $81 \%$ \\
Shrimp farms & 0 & $\mathbf{7 7}$ & 0 & 0 & 7 & 84 & $92 \%$ \\
Salt pans & 1 & 0 & $\mathbf{3 1}$ & 8 & 3 & 43 & $72 \%$ \\
Coconut & 0 & 0 & 0 & $\mathbf{5 9}$ & 5 & 64 & $92 \%$ \\
plantations & & & & & & $62 \%$ \\
Other & 0 & 8 & 7 & 23 & $\mathbf{6 2}$ & 100 & $62 \%$ \\
Total & 57 & 85 & 38 & 90 & 60 & $\mathbf{3 6 0}$ & \\
Producers's & $98 \%$ & $91 \%$ & $82 \%$ & $66 \%$ & & & \\
accuracy & & & & & &
\end{tabular}

\subsection{Carbon stocks}

299

\subsubsection{Belowground carbon stocks in mangrove forests and coconut plantations}

For this study, three abandoned shrimp ponds (Nachchikalliya: abandoned for 5 years, 303 Palavi: abandoned for 7 years and Seguwanthiv: abandoned for 13 years, Fig. 1), resulting 304 from the conversion of mangroves, as well as intact mangroves adjacent to them, were sampled in January 2014. Samples ( $n=9)$ were collected from mangrove sites using a deep soil corer. Subsamples were taken for the determination of sediment bulk density and carbon concentration at the following depths (cm): 0-5, 5-10, 10-20, 20-50, 50-100, 100-150, 150200 and 200-250. The Loss On Ignition (LOI) method was applied to the sediments

309 (Kauffman and Donato, 2012). Dry biomass was converted into carbon mass using 
310 carbon:biomass ratios of $45 \%$ (IPCC, 2014) and soil carbon storage was calculated as 311 described by Donato et al. (2012).

312 Using the pond surface area, depth and the soil bulk density at each depth interval, the amount of soil removed (in $\mathrm{kg}$ ) due to conversion into ponds was estimated. The carbon soil storage patterns prior to pond excavation were assumed to be similar to the adjacent mangrove forests. Thus, the amount of carbon lost with the removed soil for each depth interval of the ponds was obtained as the product of soil carbon content in mangroves and the

317 total soil weight removed at the same depth in ponds.

318 Coconut soil carbon content was measured using the same method. Samples $(n=7)$ were taken each time at two depths $(\mathrm{cm}): 0-15$ and $15-50$. A LOI: CN ratio of $31 \%$ was determined by analysing sediments for C:N ratio (Kauffman and Donato, 2012). Soil carbon storage was then calculated.

\subsubsection{Spatial distribution}

To estimate carbon $(\mathrm{C})$ vegetation stock balance related to land cover/use changes detected in 326 the study area between 1992/1994 and 2012, C vegetation stocks (t.ha ${ }^{-1}$ ) were taken either from the literature or from new field measurements (Table 2). Carbon gained or lost between 1992/1994-2007 and 2007-2012 for transitions between the land use categories was determined using GIS. Parameters queried for each possible combination of land-use/cover

330 change were as follows: belowground carbon (BGC), aboveground carbon (AGC), Net 331 Primary Production rates (NPP) and belowground storage rates (BS) (Table 2). Time since 332 conversion was used to calculate the sums of annual carbon increments gained or lost in 333 conversions involving mangroves. Information about the exact year of change from one land cover to another was taken from the literature when available. If a conversion from vegetation cover (mangroves or coconut plantations) to aquaculture ponds was detected between 1992/1994 and 2007, the year of conversion was estimated to be 1995 since this is recorded as the peak year in this time envelope for new aquaculture developments (IUCN 2009). On the contrary, when a return from aquaculture to vegetation cover was observed, the estimated year of conversion was 2004 as a major WSSV outbreak caused waves of decline in the industry in 2004-2005 (Munasinghe et al., 2010). No literature related to the changes in coconut plantations along the lagoon was found. Thus conversion from either coconut 
343 mid-point of the time series (in 2000 for 1992/1994-2007, or in 2009 for the 2007-2012

344 series). These assumptions were made in the absence of remote-sensed data for each year

345 between 1992-2012. Carbon stock changes induced by conversion into salt pans were assumed to be the same as for a conversion into shrimp ponds, as deforestation techniques used to clear the ponds are identical.

Table 2 Carbon stock and flow values for each vegetation cover as well as gain or loss applied to each land cover changes detected in the study area. $B G C=$ belowground carbon; $A G C=$ aboveground carbon; $N P P=n e t$ primary production; $B S=$ belowground storage rate from trapped sediment. $M=$ =mangrove; $S F=$ shrimp farms; $S P=$ salt pan; $C=$ coconut plantations. Other= land use other than mangroves, aquaculture or coconut groves. Carbon stocks are expressed in t.ha-1 $\pm S D$. If SD does not figure in the table this means the value was not given in the literature.

\begin{tabular}{|c|c|c|c|c|c|c|c|c|}
\hline & \multicolumn{2}{|c|}{$\mathrm{BGC}$} & \multicolumn{2}{|c|}{ AGC } & \multicolumn{2}{|c|}{ NPP } & \multicolumn{2}{|c|}{ BS } \\
\hline & $t C \cdot h a^{-1}$ & Source & $t C \cdot h a^{-1}$ & Source & $\begin{array}{l}t C . h a^{-} \\
{ }^{\prime} \cdot y r\end{array}$ & Source & $t C \cdot h a^{-1} \cdot y r$ & Source \\
\hline Mangrove & $\begin{array}{l}199.18 \pm \\
19.02\end{array}$ & $\begin{array}{c}\text { Field } \\
\text { measurement }\end{array}$ & 159 & $\begin{array}{l}\text { Donato } e t \\
\text { al. (2011) }\end{array}$ & 5.3 & $\begin{array}{l}\text { Alongi, } \\
\text { (2009) }\end{array}$ & $1.74 \pm 0.23$ & $\begin{array}{c}\text { Alongi, } \\
\text { (2014) }\end{array}$ \\
\hline $\begin{array}{l}\text { Coconut } \\
\text { plantation }\end{array}$ & $\begin{array}{c}34.15 \\
\pm 31.01\end{array}$ & $\begin{array}{c}\text { Field } \\
\text { measurement }\end{array}$ & 194.4 & $\begin{array}{l}\text { Mattsson } \\
\text { et al. } \\
(2009)\end{array}$ & $\mathrm{n} / \mathrm{a}$ & & $\mathrm{n} / \mathrm{a}$ & \\
\hline $\begin{array}{l}\text { Land-use } \\
\text { change } \\
\text { queries }\end{array}$ & \multicolumn{2}{|c|}{ BGC } & \multicolumn{2}{|c|}{ AGC } & \multicolumn{2}{|c|}{ NPP } & \multicolumn{2}{|c|}{ BS } \\
\hline $\mathrm{M} \rightarrow \mathrm{SF} / \mathrm{SP}$ & \multicolumn{2}{|c|}{$-186.64 \pm 26.49$} & \multicolumn{2}{|c|}{-159} & \multicolumn{2}{|c|}{-5.3} & \multicolumn{2}{|c|}{$-1.74 \pm 0.23$} \\
\hline $\mathrm{SF} / \mathrm{SP} \rightarrow \mathrm{M}$ & \multicolumn{2}{|c|}{$\mathrm{n} / \mathrm{a}$} & \multicolumn{2}{|c|}{$\mathrm{n} / \mathrm{a}$} & \multicolumn{2}{|c|}{+5.3} & \multicolumn{2}{|c|}{$+1.74 \pm 0.23$} \\
\hline $\mathrm{C} \rightarrow \mathrm{SF} / \mathrm{SP}$ & \multicolumn{2}{|c|}{$-34.15 \pm 31.01$} & \multicolumn{2}{|c|}{-194.4} & \multicolumn{2}{|c|}{$\mathrm{n} / \mathrm{a}$} & \multicolumn{2}{|c|}{$\mathrm{n} / \mathrm{a}$} \\
\hline $\mathrm{SF} / \mathrm{SP} \rightarrow \mathrm{C}$ & \multicolumn{2}{|c|}{$+34.15 \pm 31.01$} & \multicolumn{2}{|c|}{+194.4} & \multicolumn{2}{|c|}{$\mathrm{n} / \mathrm{a}$} & \multicolumn{2}{|c|}{$\mathrm{n} / \mathrm{a}$} \\
\hline $\mathrm{M} \rightarrow \mathrm{C}$ & \multicolumn{2}{|c|}{$\begin{array}{l}-199.18 \pm 19.02 \\
+34.15 \pm 31.01\end{array}$} & \multicolumn{2}{|c|}{$\begin{aligned} & -159 \\
+ & 194.4\end{aligned}$} & \multicolumn{2}{|c|}{$\mathrm{n} / \mathrm{a}$} & \multicolumn{2}{|c|}{$\mathrm{n} / \mathrm{a}$} \\
\hline $\mathrm{C} \rightarrow \mathrm{M}$ & \multicolumn{2}{|r|}{$\mathrm{n} / \mathrm{a}$} & \multicolumn{2}{|c|}{-194.4} & \multicolumn{2}{|c|}{+5.3} & \multicolumn{2}{|c|}{+1.74} \\
\hline $\begin{array}{l}\text { M-No } \\
\text { change }\end{array}$ & \multicolumn{2}{|r|}{$\mathrm{n} / \mathrm{a}$} & \multicolumn{2}{|c|}{$\mathrm{n} / \mathrm{a}$} & \multicolumn{2}{|c|}{+5.3} & \multicolumn{2}{|c|}{+1.74} \\
\hline$M \rightarrow$ other & \multicolumn{2}{|r|}{$\mathrm{n} / \mathrm{a}$} & \multicolumn{2}{|c|}{-159} & & 5.3 & -1 & \\
\hline
\end{tabular}




\subsection{Establishing the number of working shrimp ponds}

In order to understand the degree of abandonment of shrimp ponds in Puttalam lagoon, highresolution images from 2011 on Google Earth were manually analysed. Shrimp ponds were distinguished from salt pans based on their size: ponds exceeding 50x50m size were always classified as shrimp ponds.

Functioning and non-functioning ponds were distinguished using various features. When the boundaries of ponds were even and well shaped, the ponds and/or dykes were free from any type of vegetation (i.e. herbs, bushes or trees) and not submerged by water; if they were full of homogeneous water and some aerators were present then it was classified as a functioning pond.

The dimensions of functioning/non-functioning ponds were measured using Google Earth tools, allowing calculations of their areas. The first three of the abovementioned factors were compulsory in categorising a pond as functioning. In order to ground truth the results, field visits and interviews $(\mathrm{n}=20)$ with local people were carried out.

\section{Results}

\subsection{Land use changes between 1992/1994 and 2012}

The outlines of the land use classification varied depending on the type of image (aerial photograph, SPOT 5 or Pleiades). In order to compare patterns of land use/cover between 1992/1994, 2007 and 2012, images were extracted by mask within ArcGIS to show the same area and thus be comparable. The quantifications of change in land use between 1992/1994 and 2012 are shown in table 3. There was a dramatic expansion of shrimp farms during this period (+ 2777\%, Table 3). Highlighted in Fig. 3 is the Mee-Oya estuary on the east of the lagoon that represents these patterns of change.

The rate of growth in the area of shrimp farms was higher between 1992/1994 and 2007, with an increase of 71 ha year ${ }^{-1}$, compared with a slower rate of 23 ha year $^{-1}$ between 2007 and 2012 (Table 4). On the contrary, the area of salt pans increased faster between 2007 and 2012

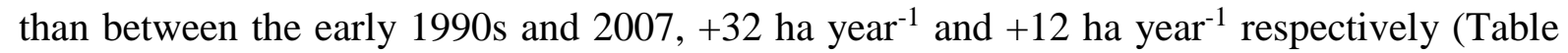
4). The area of coconut plantations increased more between 1992/1994 and 2007 than between 2007-2012, +27 ha year ${ }^{-1}$ and +10 ha year $^{-1}$ respectively (Table 4). Mangroves were 
392 lost at a rate of 27 ha year ${ }^{-1}$ between 1992/1994 and 2007, while they increased by 3 ha year ${ }^{-1}$ 393 between 2007 and 2012.

Table 3 Land use areas in 1992/1994 and 2012 in Puttalam lagoon. Ratios of the area of shrimp farm (SF) to mangrove (M), and of shrimp farm (SF) to coconut plantation (CP) are indicated in the table, as well as the changes in land use areas between the beginning of the 90s and 2012. Percentages in brackets represent 398 the percentage of total land areas.

399

\begin{tabular}{cccc}
\hline Land use & $1992 / 1994(\mathrm{ha})$ & $2012(\mathrm{ha})$ & Net Change $(\%)$ \\
\hline Shrimp farms & $39.63(1 \%)$ & $1140.3(20 \%)$ & +2777.3 \\
Salt pans & $539.3(13 \%)$ & $862.1(15 \%)$ & +59.8 \\
Mangroves & $1093.7(26 \%)$ & $726(13 \%)$ & -33.6 \\
Coconut plantations & $2535(60 \%)$ & $2963.6(52 \%)$ & +16.9 \\
SF: M ratio & $1: 28$ & $1: 0.6$ & \\
SF: CP ratio & $1: 64$ & $1: 2.6$ & \\
\hline
\end{tabular}

400

401

402

403

Table 4 Hectares of each land use lost or gained per year for the Puttalam lagoon, based on the analysis of 404 image classification between 1992/1994-2007 and 2007-2012.

405

\begin{tabular}{ccc}
\hline Land use & 1992/1994-2007 $\left(\mathrm{ha} \mathrm{yr}^{-1}\right)$ & $2007-2012\left({\left.\mathrm{ha} \mathrm{yr}^{-1}\right)}^{-1}\right.$ \\
\hline Shrimp farms & +71 & +23 \\
Salt pans & +12 & +32 \\
Mangroves & -27 & +3 \\
Coconut plantations & +27 & +9.9 \\
\hline
\end{tabular}


406

407

408

409

410

411

412

413

414

415

416

417

418

419

420

421

422

423

424

425

426

427

428

429

430

431

432

433

434

435

436

437

438

439

440

441

442

443

444

445

446

447

448

449

450

451

452

453

Figure 3 Time series for the four land uses classified in this study in Puttalam lagoon, with a zoom in the Mee-Oya estuary, clearly showing expansion of shrimp farms and salt pans and loss of the coastal mangrove ecosystem between 1992/4 and 2012.

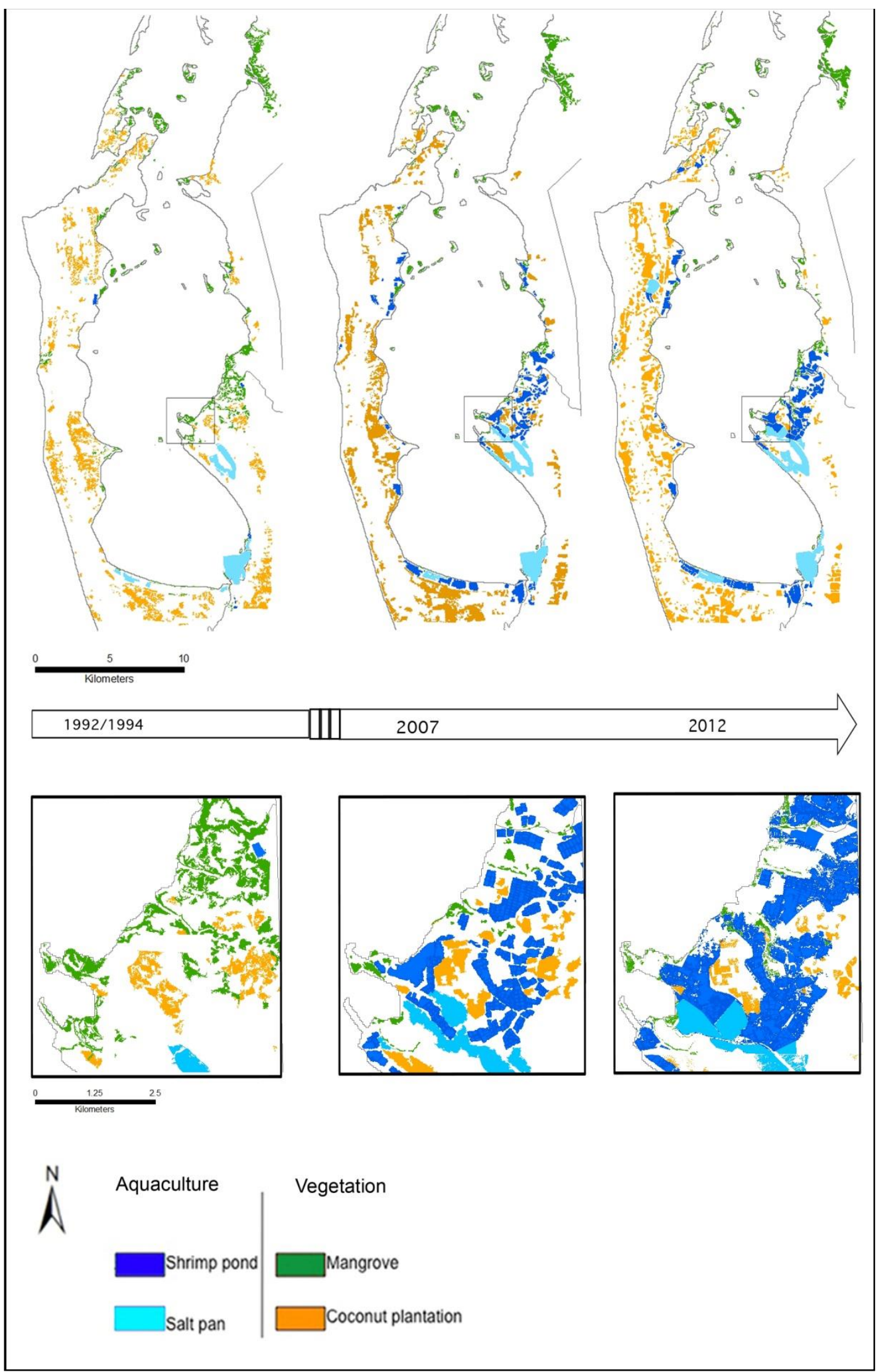




\subsection{Impacts of shrimp farming on carbon dynamics between 1992/1994-2012}

Figure 4 shows changes in carbon stocks between the early 1990s and 2012; it was obtained by superimposing carbon gain/loss in 1992/1994-2007 and 2007-2012 (Supplementary material table S1). The important areas of carbon accumulation are mostly located at the NE of the lagoon, which is an area of mangrove forest with no aquaculture infrastructure. Therefore, this area represents the capacity of mangroves as carbon stores when they are not subject to intense deforestation. Losses of $>2000$ tC have taken place mainly in areas where mangroves were replaced by aquaculture ponds. The conversion from mangroves to shrimp farms represents $24 \%$ all land cover changes to aquaculture observed between 1990s-2007, which is the second largest proportion of land use changes due to aquaculture observed around the lagoon (Fig. 5). The largest proportion of change is the conversion of 'Other' to aquaculture, which includes mainly coastal vegetation (Fig. 5). A decrease of the conversion from mangroves to shrimp farms can be observed between 2007-2012 (Fig. 5). During the first time period of the study, $34 \%$ of mangroves were converted to shrimp ponds, and $23 \%$ to other land use, which includes agricultural uses and housing areas (Table 5). Between 2007-2012 this conversion from mangroves to other land uses increased, with $32 \%$ of mangroves present in 2007 lost in 2012 to 'Other' (Table 5). 41\% and 59\% of the mangroves present in 1990s and 2007 respectively have not changed and have accumulated a total of 52 892 tC in 1990s-2012 (Table 5, S1), which represents by itself the major carbon accumulation along the lagoon for the study period. The conversion of mangroves to ponds (shrimp farms and salt ponds) led to a loss of 186359 tC between 1990s-2012, whilst the conversion of coconut plantations into ponds accounted for $2502 \mathrm{tC}$ lost in Puttalam (S1). Therefore, the conversion of mangrove into aquaculture ponds represents the most significant carbon loss. The overall carbon loss in the study area for the time period 1990s-2012 was 191 $584 \mathrm{tC}(\mathrm{S} 1)$.

(1)

. 
501

502

503

504

505

506

507

508

509

510

511

512

513

514

515

516

517

518

519

520

521

522

523

524

525

526

527

528

529

530

531

532

533

534

Table 5 Combinations of land-use and their proportion of loss. $M=$ =mangroves; $S F=$ shrimp farms; $S P=s a l t$ pans; $C=$ coconut plantations; other= other land-use. No change represents unchanged areas.

\begin{tabular}{|c|c|c|c|c|}
\hline & \multicolumn{2}{|c|}{ Area converted (ha) } & \multicolumn{2}{|c|}{ Loss as \% of original LC } \\
\hline & 1992/1994-2007 & $2007-12$ & 1992/1994-2007 & $2007-12$ \\
\hline $\mathrm{C} \rightarrow \mathrm{M}$ & 1.12 & 1.38 & 0.04 & 0.05 \\
\hline $\mathrm{C} \rightarrow \mathrm{SF}$ & 3.73 & 4.83 & 0.15 & 0.17 \\
\hline $\mathrm{C} \rightarrow \mathrm{SP}$ & 0.21 & 2.17 & 0.01 & 0.07 \\
\hline C- no change & 1279.72 & 1647.91 & 50.48 & 56.54 \\
\hline $\mathrm{C} \rightarrow$ other & 1250.27 & 1258.08 & 49.32 & 43.17 \\
\hline $\mathrm{M} \rightarrow \mathrm{C}$ & 15.57 & 0.48 & 1.42 & 0.07 \\
\hline $\mathrm{M} \rightarrow \mathrm{SF}$ & 374.67 & 64.34 & 34.26 & 9.05 \\
\hline $\mathrm{M} \rightarrow \mathrm{SP}$ & 2.28 & 1.71 & 0.21 & 0.24 \\
\hline M- no change & 446.92 & 418.73 & 40.86 & 58.90 \\
\hline $\mathrm{M} \rightarrow$ other & 252.9 & 226.36 & 23.12 & 31.84 \\
\hline $\mathrm{SF} \rightarrow \mathrm{C}$ & 0.002 & 0.25 & 0.01 & 0.02 \\
\hline $\mathrm{SF} \rightarrow \mathrm{M}$ & 0.28 & 1.02 & 0.71 & 0.10 \\
\hline $\mathrm{SF} \rightarrow \mathrm{SP}$ & 0 & 23.69 & 0 & 2.31 \\
\hline SF- no change & 26.48 & 775.13 & 66.82 & 75.54 \\
\hline $\mathrm{SF} \rightarrow$ other & 12.87 & 225.91 & 32.48 & 22.02 \\
\hline $\mathrm{SP} \rightarrow \mathrm{M}$ & 0.52 & 0.001 & 0.10 & 0 \\
\hline $\mathrm{SP} \rightarrow \mathrm{C}$ & 0 & 0.02 & 0 & 0 \\
\hline $\mathrm{SP} \rightarrow \mathrm{SF}$ & 32.14 & 19.83 & 5.96 & 2.82 \\
\hline $\mathrm{SP}-$ no change & 458.53 & 631.09 & 85.02 & 89.75 \\
\hline $\mathrm{SP} \rightarrow$ other & 48.63 & 52.25 & 9.02 & 7.43 \\
\hline
\end{tabular}


Figure 4 Carbon dynamics in Puttalam lagoon between 1992/1994 and 2012, with a zoom in the Mee-Oya estuary, which equates to a carbon loss of $>2000 t C$ with mangrove conversion to aquaculture.

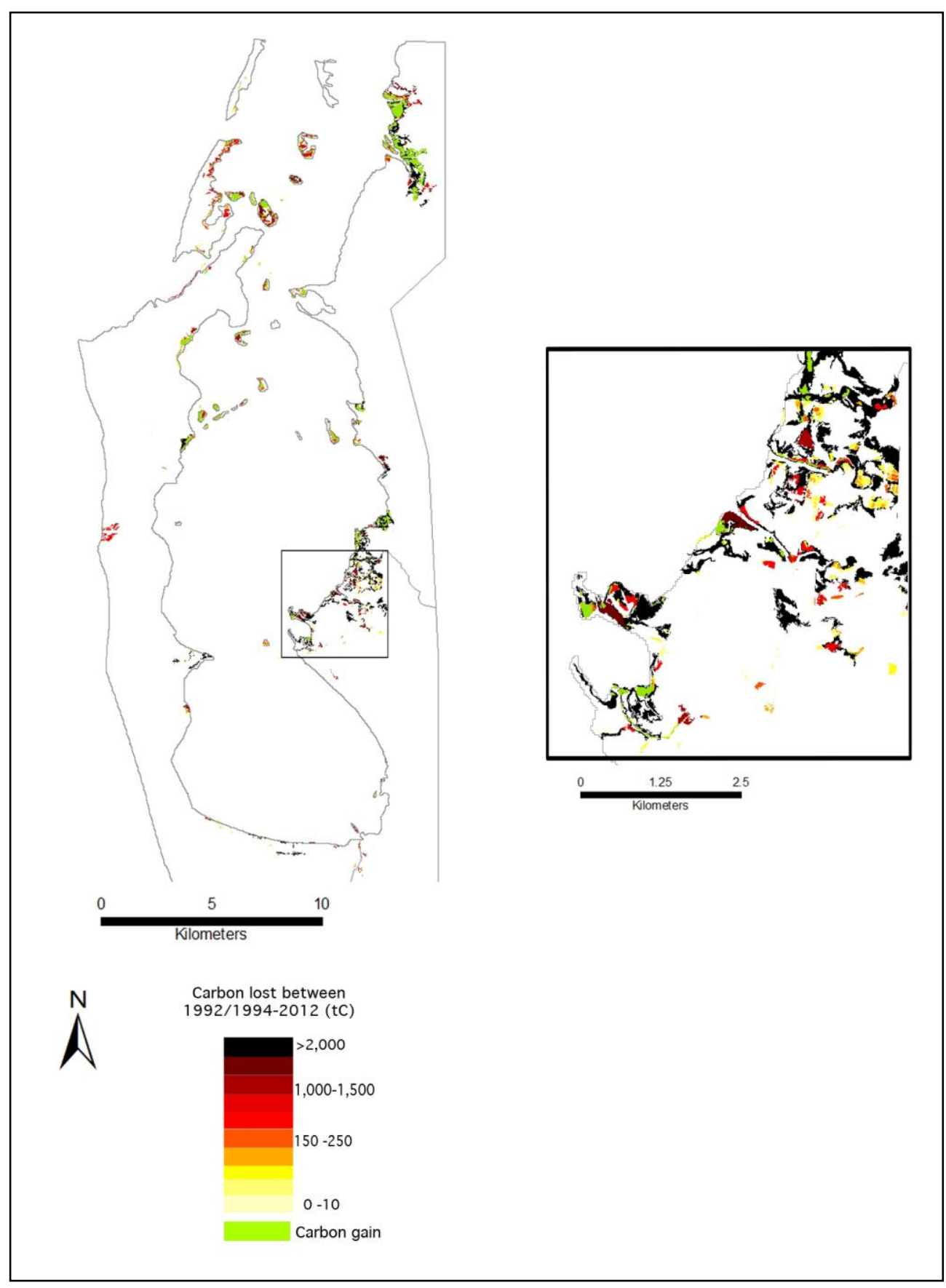


$583 \quad$ Figure 5 The proportion of land cover/land use types converted to aquaculture around Puttalam lagoon 584 between a) 1990s-2007 and b) 2007-2012.

585

586

587

588

589

590

591

592

593

594

595

596

597

598

599

600

601

602

603

604

605

606

607

608

609

610

611

612

613

614

615

616

617

618

619

620

621

622

623

624

625

626

627

628

629

630

a)

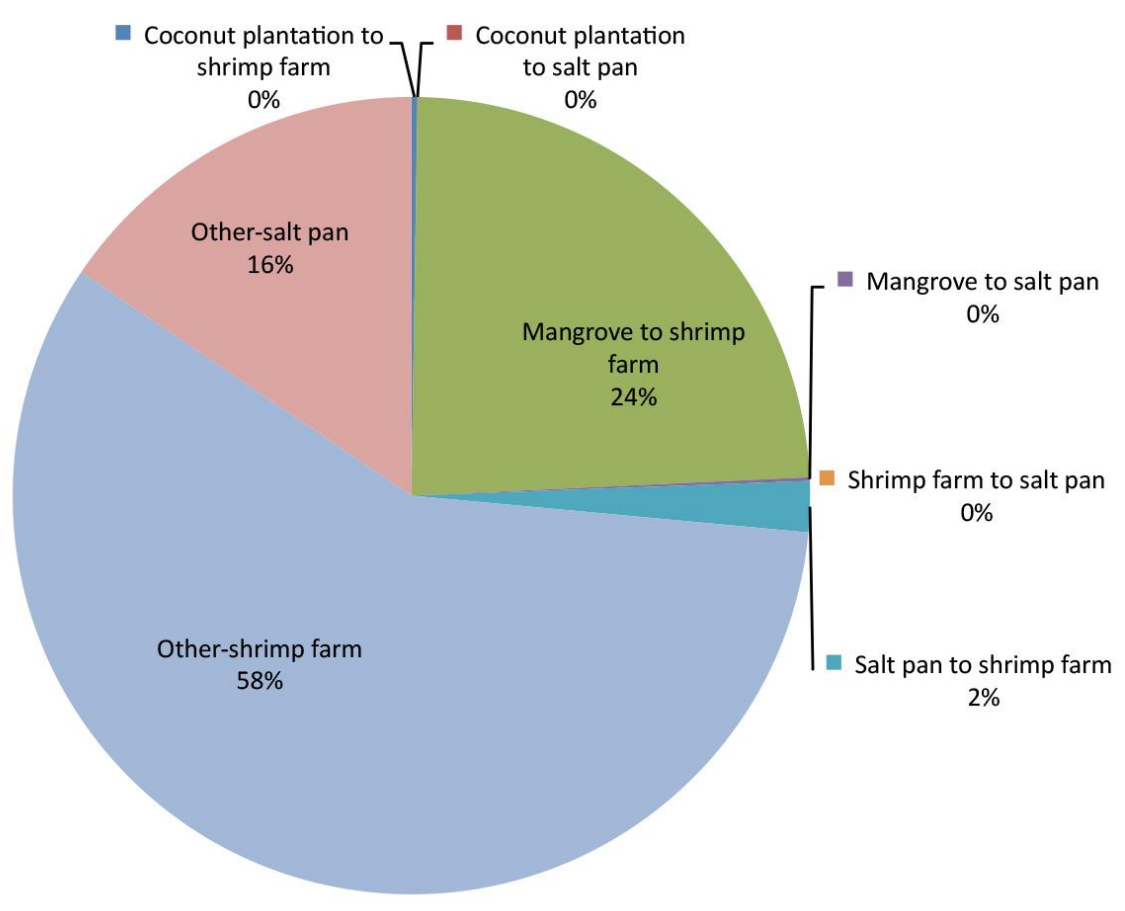

b)

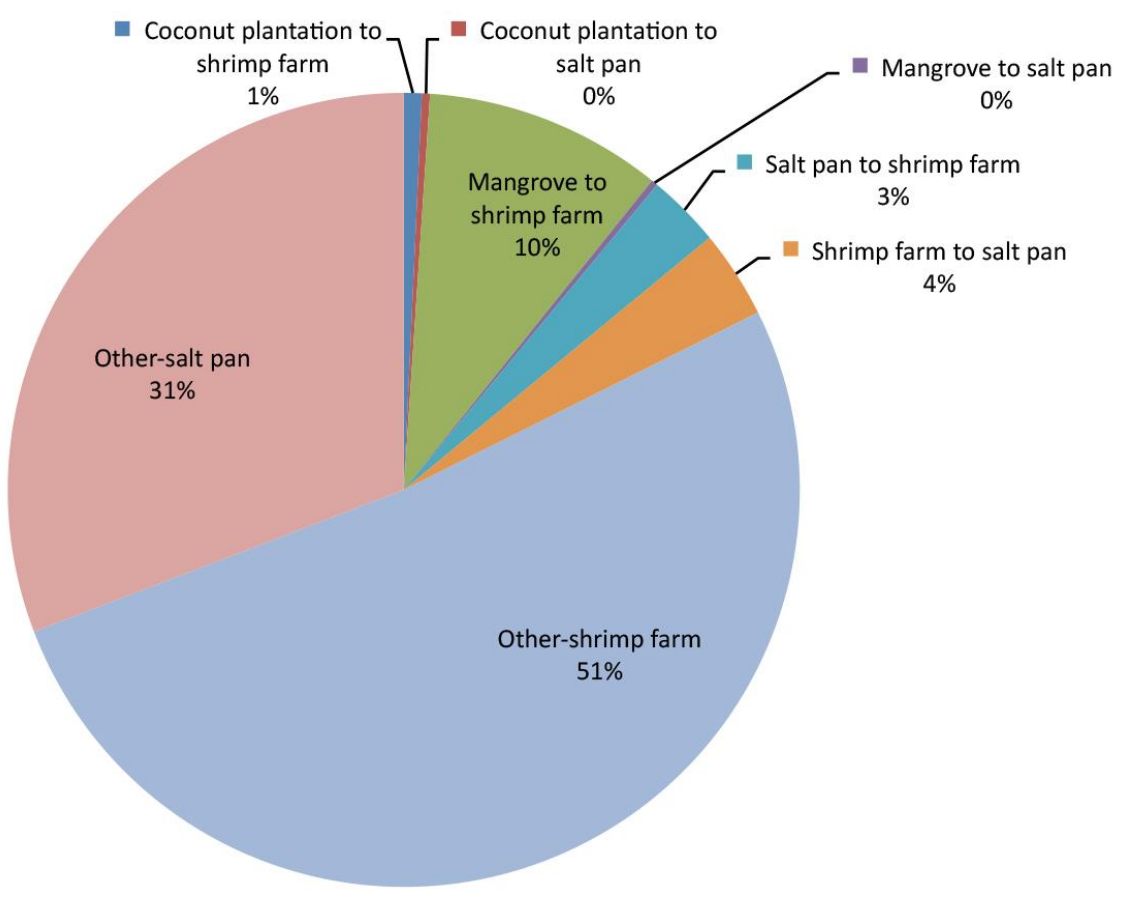


650

651

\subsection{Estimate of the current functioning shrimp farms area}

Only $10 \%$ of the shrimp ponds in Puttalam lagoon were classified as currently productive, leaving a large area of ponds unused. This number suggests a continuing decline in shrimp farming viability around the lagoon, as $75 \%$ of farms were estimated to be non-operational in 2008 (Pathirana et al., 2008).

\section{Discussion}

4.1 The extent of shrimp farming in the Puttalam lagoon: impacts on land use/cover change since 1992-1994.

GIS and remote sensing techniques are potentially powerful tools to support the sustainable management of shrimp aquaculture. Studies in India (Hossain et al., 2003; Kumaran et al., 2003), Brazil (Cavalcanti Maia Santos et al., 2014), Mexico (Sanchez et al., 2003), Bangladesh (Salam and Ross, 2000; Quader et al., 2004), Thailand (Tripathi et al., 2000) and Vietnam (Tong et al., 2004; Giap et al., 2005) give different case studies on how GIS and remote sensing can be used to inform the management of shrimp culture. The present study adds to the literature on this matter.

Previous studies of land use change caused by shrimp farming in the Puttalam lagoon used aerial surveys conducted in the Puttalam district between 1981 and 1992 (Senarath and Visvanathan, 2001; Pathirana et al., 2008). The latest national forest inventory data available for Sri Lanka are from 1992-1996 (Mattsson et al. 2012). Therefore, the time series presented here provides a more recent and comprehensive picture of the impacts of aquaculture development in the Puttalam lagoon.

The ratio of mangrove forests to shrimp farms changed from 28:1 at the beginning of the 1990s to 0.6:1 in 2012 (Table 3). These observations concur with studies of other sites on the west Sri Lankan coast. In Chilaw, Dahdouh-Gubeas et al. (2001) recorded a ratio of mangroves to shrimp farms of 2.6:1 in 1998 and noticed a historical trend towards 1:1, with increasingly fewer mangroves and more shrimp ponds. The current results suggest that shrimp farming dynamics are likely to be similar among lagoons in the NWP of Sri Lanka. 
665 Between 1981 and 1992, 64\% of the mangrove area in Puttalam was lost (Senarath and 666 Visvanathan, 2001). Approximately 34\% of the remaining mangrove area has been lost 667 between 1992/1994 and 2012 in Puttalam (Table 3). Hence it appears that the rate of 668 mangrove destruction around the lagoon has decreased in recent decades, with a slight 669 increase in mangrove coverage in the final five years of our study. Mangrove loss observed 670 during the 1980s and 1990s was mostly caused by the initiation of shrimp farming in the 671 NWP, but could also be partly attributed to increased pressure from local populations; about $67255 \%$ of house-holds used mangrove as firewood in the mid-1980s, and this consumption 673 further increased with an influx of political refugees in the west of the country (Senarath and 674 Visvanathan, 2001; Pathirana et al., 2008; Ranasinghe, 2010).

675

676 Of the various types of land-use considered in the present study, 41\% and 59\% is represented 677 by mangrove area that remained forested between 1990s-2007 and 2007-2012 respectively 678 (Table 5). When considering only land use changes over the studied period, 34\% of 679 mangroves were converted to shrimp farms between 1990s-2007, which is by far the largest 680 category of land-use change concerning mangroves (Table 5). This trend has changed more 681 recently, with $9 \%$ of mangroves that were converted to shrimp ponds between 2007 and 682 2012, leaving their conversion to other land uses becoming the major conversion occurring around the lagoon (32\%, Table 5). The land uses included in this miscellaneous category were not classified using GIS. Our knowledge of the field site suggests that they include 685 conversion to other agricultural land uses (including paddy fields), loss to buildings, to scrub or other coastal vegetation and to water.

687

688 Shrimp farms around Puttalam lagoon were mainly constructed on areas previously occupied 689 by coastal vegetation (classified as 'other' in this study). Nevertheless, a significant 690 proportion of these ponds also replaced mangrove areas, especially between 1992/1994-2007, 691 with $24 \%$ of land-use conversion to aquaculture attributed to the change from mangrove to 692 shrimp ponds (Fig. 5). This result shows that the impact of shrimp farms on mangroves in 693 Puttalam follows the dramatic trend of other countries where land cover changes related to 694 shrimp culture have recently been studied. For instance, $23.9 \%$ of mangrove cover has been 695 converted to shrimp farms between 1999 and 2008 in Ha Long, Vietnam (Bui et al., 2014).

696 
697 Only two salt ponds were present in the Puttalam area at the beginning of the 1990s (Fig. 3).

698 The salt industry also contributed, albeit to a lesser extent, to the loss of mangroves; in $6991992 / 1994$ only $13 \%$ of the lagoon was used for this purpose compared to $15 \%$ in 2012 700 (Table 3). Finally, conversion of mangroves to coconut plantations accounted for only a small 701 percentage of total land changes (1.42\% and $0.07 \%$ in 1990 s-2007 and 2007-2012 702 respectively, Table 5). However, the high carbon density of mangroves means this still 703 resulted in a loss of some 2081 tC between the early 1990s and 2012.

704

705 Whilst large areas of valuable mangrove forest have been lost, this has not resulted in 706 permanent (or even extended) economic benefits for local people. Intensive shrimp farms 707 have a relatively short initial productive life, with problems of disease and pollution often 708 leading to permanent or temporary abandonment after 5 to 10 years. Stevenson (1997) 709 described this problem in Thailand and estimated that 'up to 70\%' of all farms in the study 710 area were abandoned. Our data show that the situation in Puttalam is worse than this, with $71190 \%$ of farms abandoned; because of the criteria used to identify abandonment, which 712 included the growth of vegetation which will take many years to establish, this estimate may 713 be conservative. Pond abandonment results in large areas of unoccupied land unsuitable for 714 most uses because of the unfavourable chemical and physical properties of the soil, which 715 include low pH and loss of organic structure (Towatana et al., 2003).

717 Between the early 1990s and 2012, shrimp farms in Puttalam have been converted into 718 coconut plantations at a constant rate of $0.02 \%$ (Table 5). Some natural mangrove 719 regeneration can be observed in abandoned ponds, with $0.71 \%$ and $0.010 \%$ of shrimp farm 720 area classified as returning to mangroves during 19902/1994-2007 and 2007-2012 721 respectively (Table 5). However natural recovery of these ponds is likely to remain very 722 slow, due to limits on the dispersal ability of propagules (Di Nitto et al., 2013) as well as the 723 chemical and physical unsuitability of the sediments.

725 Most shrimp farms in Puttalam were constructed illegally, thus appropriate site selection was 726 not performed (Cattermoul and Devendra, 2002; Dahdouh-Guebas et al., 2001). Mangrove 727 areas are able to buffer the impacts of effluents from ponds in surrounding areas hence 728 retaining mangroves is one way of helping to ensure sustainability and avoiding collapse. The 
729 low ratio of mangrove to shrimp farms (abandoned or operational) in Puttalam estimated in 730 the current study (0.6:1 in 2012, Table 3) will have contributed to the high rate of 731 abandonment and the slow rates of recovery of ponds.

732

733 The Sri Lankan government still considers aquaculture as an important industry for further 734 development (Department of National Planning, 2013). There is also now strong demand 735 from the EU for sustainable shrimp products (Lei, 2012). Therefore, there is policy and 736 economic potential for the rehabilitation of some of the abandoned ponds, which must 737 involve careful planning to ensure a correct balance between mangroves and aquaculture. 738 Achieving this would involve active policy support and intervention and must learn from the mistakes of the past two decades, linking development to sustainability, climate change

740 adaptation and mitigation (Harkes et al., in prep.).

741

742

743

744

745

746

747

748

749

750

751

752

753

754

755

756

757

758

759

760

\subsection{Impacts of shrimp farming on carbon storage and sequestration}

The exceptional ability of mangrove forests to sequester carbon and to store it belowground makes carbon storage one of their most important regulating ecosystem services. By assessing land-use changes in Puttalam during the two last decades, the present study underlines the consequences of these dynamics for carbon stores. The land use patterns studied in this research have caused a net loss of stored carbon of 191584 tC between 1992/1994 and 2012. The conversion of vegetated areas into aquaculture ponds represents a total loss of $188861 \mathrm{tC}$ in the 19-year period (S1). Mangroves were converted into coconut plantations, especially between 1992/1994 and 2007, leading to a loss of some 2081 tC during the last two decades (S1). Reconversion of aquaculture ponds into vegetation is a minor change, which has produced a total sequestration of $103 \mathrm{tC}$, contributing only an estimated $0.2 \%$ of the total $\mathrm{C}$ accumulation in Puttalam over the study period.

\section{Conclusion}

This study shows that Puttalam lagoon has experienced significant land use changes in the past two decades. There are implications for a range of ecosystem services; here we document the effects on one, carbon sequestration, with a net loss of $191584 \mathrm{tC}$ in the 19year period. It is obvious that the development of shrimp farming has had a negative impact 
761 on the coastal environment in Puttalam, and the loss of ecosystem services has not been

762 balanced by permanent economic benefits since $90 \%$ of ponds are now abandoned.

764 The results presented in this paper emphasise the requirement for integrated planning in the 765 Puttalam area. Most of the aquaculture in the study area is currently unproductive, has lost 766 natural ecosystem services such as carbon sequestration and has increased vulnerability to 767 natural hazards and climate change. Therefore there is a pressing need for reconversion or 768 rehabilitation of abandoned ponds in Puttalam lagoon. The findings of this study highlight the 769 need for more control over pond site selection and shrimp farming licences. The economic and ecological advantages in implementing sustainable aquaculture practices in Puttalam are potentially considerable.

772

\section{Acknowledgements}

774

775

776

777

778

779

780

781

782

783

784

785

786

787

788
This work formed part of the iCoast project, which was funded by the Climate \& Development Knowledge Network (CDKN) and carried out by Edinburgh Napier University (lead), LTS International, Birmingham University, KMFRI, Ruhuna University in Sri Lanka, in collaboration with Ecometrica and the Environment Management Group. We are grateful to Ingvild Harkes who commented on earlier drafts and helped organise the work.

This document is an output from a project funded by the UK Department for International Development (DFID) and the Netherlands Directorate-General for International Cooperation (DGIS) for the benefit of developing countries. However, the views expressed and information contained in it are not necessarily those of or endorsed by DFID, DGIS or the entities managing the delivery of the Climate and Development Knowledge Network, which can accept no responsibility or liability for such views, completeness or accuracy of the information or for any reliance placed on them.

\section{References}

Alongi D.M. (2002) Present State and Future of World's Mangrove Forests. Environmental Conservation 29: 331-349.

Alongi D.M. (2009) The energetics of mangrove forests. Springer, Berlin. 216pp. 
Alongi D.M. (2012) Carbon sequestration in mangrove forests. Carbon management. 3(3): 313-322.

Alongi D.M. (2014) Carbon cycling and storage in mangrove forests. Annual review of

Amarasinghe M.D. (1988) Socio-economic status of the human communities of selected mangrove areas on the west coast of Sri Lanka. UNESCO, Occ. Pap. 3. UNDP/UNESCO.

Bandaratillake H.M., Sarath Fernando M.P. (2003). National forest policy review: Sri Lanka. In: Enters, T., Qiang, M., Leslie, R.N. (Eds.), An Overview of Forest Policies in Asia. FAO, Bangkok.

Bergquist D.A. (2007) Sustainability and Local People's Participation in Coastal Aquaculture: Regional Differences and Historical Experiences in Sri Lanka and the Philippines. Environmental Management. 40:787-802.

Bosma R.H and Verdegem M.C.J. (2011) Sustainable aquaculture in ponds: Principles, practices and limits. Livestock Science 139:58-68.

Bui T.D., Maier S.W. and Austin C.M. (2014) Land cover and land use change related to shrimp farming in coastal areas of Quang Ninh, Vietnam using remotely sensed data. Environmental Earth Sciences. 72: 441-455.

Cavalcanti Maia Santos L., Matos H.R., Schaeffer-Novelli Y., Cunha-Lignon M., Bitencourt M.D., Keadam N. and Dahdouh-Guebas F. (2014) Anthropogenic activities on mangrove areas (Sao Francisco River Estuary, Brazil Northeast): A GIS-based analysis of CBERS and SPOT images to aid in local management. Ocean and Coastal Management. 89:39-50.

Carney J., Gillespie T.W . and Rosomoff R. (2014) Assessing forest change in a priority West African mangrove ecosystem: 1986-2010. Geoforum. 53:126-135.

Cattermoul N. and Devendra A. (2002) Effective management for biodiversity conservation in Sri Lankan coastal wetlands: the ecological footprint of shrimp farming in Chilaw. University of Portsmouth, fieldwork report 2.3a.

Dahdouh-Guebas F., Zetterstöm T., Rönnbäck P., Troell M., Wickramasinghe A. and Koedam N. (2001) Recent changes in land-use in the Pambala-Chilaw lagoon complex (Sri Lanka) investigated using remote sensing and GIS: conservation of mangroves vs. development of shrimp farming. Environment, Development and Sustainability. 4:185-200.

Dayananda L.P.D. (2004) Enhancing Sustainable Livelihoods: A Case Study from Wanathavilluwa, Sri Lanka. Occ. Pap. IUCN, Sri Lanka, 6 III, 36 pp.

Department of National Planning (2013) Mahinda Chintana Vision for the Future. Public Investment Strategy 2014-2016. Department of National Planning \& Ministry of Finance and Planning. 
844 Dierberg F.E. and Kiattisimkul W. (1996) Issues, Impacts, and Implications of Shrimp 845 Aquaculture in Thailand. Environmental Management. 20:649-666.

846

847

848

849

850

851

852

853

854

855

856

857

858

859

860

861

862

863

864

865

866

867

868

869

870

871

872

873

874

875

876

877

878

879

880

881

882

883

884

885

886

887

888

889

890

891

Di Nitto D., Erftemeijer P.L.A., van Beek J.K.L., Dahdouh-Guebas F., Higazi L., Quisthoudt K., Jayatissa L.P. and Koedam N. (2013) Modelling drivers of mangrove propagule dispersal and restoration of abandoned shrimp farms. Biogeosciences. 10:5095-5113.

Donato D.C., J. Kauffman J.B., Murdiyarso D., Kurnianto S., Stidham M. and Kanninen M. (2011) Mangroves among the most carbon-rich forests in the tropics. Nature Geoscience 4: 293-297

Donato D.C, Kauffman J.B., Mackenzie A., Ainsworth A. and Pfleeger A.Z. (2012) Wholeisland carbon stocks in the tropical Pacific: Implications for mangrove conservation and upland restoration. Journal of Environmental Management 97:89-96.

Drengstig A. (2013) Aquaculture in Sri Lanka : history, current status and future potential. A short communication. AquaNor Exhibition, Trondheim, Norway.

EJF (2004) Farming The Sea, Costing The Earth: Why We Must Green The Blue Revolution. Environmental Justice Foundation, London, UK.

Giap D.H., Yi Y. and Yakupitiyage A. (2005) GIS for land evaluation for shrimp farming in Haiphong of Vietnam. Ocean and Coastal Management 48: 51-63.

Government of Sri Lanka (2000) . Initial National Communication under the United Nations Framework Convention on Climate Change. Colombo, Sri Lanka.

Harkes I., Drengstig A., Kumara M.P. and Emerton L. (2014, in prep) Shrimp aquaculture and potential for Climate Compatible Development in Sri Lanka - A case of Puttalam lagoon.

Hossain M.Z., Muttitanon W., Tripathi N.K. and Phillips M. (2003) Monitoring shrimp farming development from the space. GIS Development 7:1-6.

Huxham M., Emerton L., Kairo J., Munyi F., Abdirizak H., Muriuki T., Nunand F. and Briers R.A. (2015) Applying Climate Compatible Development and Economic Valuation to Coastal Management: A Case Study of Kenya's Mangrove Forests. Journal of Environmental Management (in press).

IPCC (2014) 2013 supplement to the 2006 IPCC guidelines for national greenhouse gas inventories: wetlands. Hiraishi T., Krug T., Tanabe K., Srivastava N., Baasansuren J., Fukuda M. and Troxler T.G. (eds). Published: IPCC, Switzerland.

IUCN (2009) Prawn farms: the Supreme Court and IUCN: on the ground impediments to conservation. BMZ Project Case Studies.

Jayatissa L.P., Dahdouh-Guebas F. and Koedam N. (2002) A revision of the floral composition and distribution of mangroves in Sri Lanka. Botanical Journal of the Linnaean Society. 138:29-43 
Kauffman J.B. and Donato D.C. (2012) Protocols for the measurement, monitoring and reporting of structure, biomass and carbon stocks in mangrove forests. Working Paper 86. CIFOR, Bogor, Indonesia.

Kumaran M., Ponnusamy K. and Kalaimani N. (2003) Diffusion and adoption of shrimp farming technologies. Aquaculture Asia. 8:20-23.

Lei (2012) Sri Lanka Seafood Exports - Quick Scan of the EU Market Potential. Compiled for the Centre for the Promotion of Imports from Development Countries (CBI) by Wageningen University.

Mattsson E., Ostwald M., Nissanka S.P., Holmer B. and Palm M. (2009) Recovery and protection of coastal ecosystems after tsunami event and potential for participatory forestry CDM- Examples from Sri Lanka. Ocean and Coastal Management. 52:1-9.

Mattsson E., Persson U.M, Ostwald M. and Nissanka S.P. (2012) REDD+ readiness implications for Sri Lanka in terms of reducing deforestation. Journal of Environmental Management. 100:29-40.

Munasinghe M.N., Stephen G., Abeynayake P. and Abeygunawardena I.S (2010) Shrimp farming practices in the Puttalam District of Sri Lanka: implications for disease control, industry sustainability and rural development. Veterinary Medicine International. Article ID 679130, 7 pages.

Pathirana K.P.P., Kamal A.R.I, Riyas M.C. and Safeek A.L.M (2008) Management of coastal resources in Puttalam lagoon, Sri Lanka. Copedec VII. P-06

Pernetta J.C. (1993) Marine protected area needs in the south Asian seas region. Volume 5: Sri Lanka. A marine Conservation and Development Report. IUCN, Gland, Switzerland, VII, $67 \mathrm{pp}$.

Primavera J.H. (1997) Socio-economic impacts of shrimp culture. Aquaculture Research. 28:815-827.

Primavera J.H. (2006) Overcoming the impacts of aquaculture on the coastal zone. Ocean and Coastal Management. 49:531-545.

Quader O., Islam Z., Rahman H., Rahman M., Sarkar M.H. and Khan A.S. (2004) Suitable site selection of shrimp farming in the coastal areas of Bangladesh using remote sensing techniques (4S Model). In: Proceedings of the XXth ISPRS (International Society for Photogrammetry and Remote Sensing) Congress. Istanbul, Turkey, July 12-23. ISPRS, Istanbul, Turkey.

Rajitha K., Mukherjee C.K. and Vinu Chandran R. (2007) Applications of remote sensing and GIS for sustainable management of shrimp culture in India. Aquacultural Engineering 36:1-17. 
940 Ranasinghe T. (2010) A sustainable financing and benefit-sharing strategy for conservation 941 and management of Puttalam lagoon. Colombo: Ecosystems and Livelihoods Group Asia, 942 IUCN, VII, 62pp.

944 Robin M., Renoux E., Debaine F., Rakatonavalona Hobialisoa D. and Lamberts C. (2010) 945 Cartographie de la mangrove du delta de la Mahajamba par classification d'une image SPOT

Salam M.A. and Ross L.G. (2000) Optimizing site selection for development of shrimp (Penaeus monodon) and mud crab (Scylla serrata) culture in Southwestern Bangladesh. In: 14th Annual Conference on Geographic Information Systems, Proceedings of the GIS'2000, Toronto, Canada, March 13-16.

Sanchez P.E., Muir J.F. and Ross L.G. (2003) GIS-based aquaculture development modelling for Tabasco coastal zone, Mexico. Ocean and Coastal Management 46:681-700.

Satyanarayana B., Mulder S., Jayatissa L.P. and Dahdouh-Guebas F. (2013) Are the mangroves in the Galle-Unawatuna area (Sri Lanka) at risk? A social-ecological approach involving local stakeholders for a better conservation policy. Ocean and Coastal Management. 71:225-237.

Senarath U. and Visvanathan C. (2001) Environmental issues in brackish water shrimp aquaculture in Sri Lanka. Environmental Management. 27:335-348.

Stevenson N. (1997) Disused shrimp ponds: Options for redevelopment of mangroves. Coastal Management 25, 425-435.

Thornton C., Shanahan M. and Williams J. (2003) From Wetlands to Wastelands: Impacts of Shrimp Farming. SWS bulletin 48-53.

Tong P.H.S, Auda Y., Populus J., Aizpuru M., Habshi A.A.L. and Balsco F (2004) Assessment from space of mangroves evolution in the Mekong delta, in relation to extensive shrimp farming. International Journal of Remote Sensing. 25:4795-4812.

Towatana P., Voradej C. and Leeraphante N. (2003) Reclamation of abandoned shrimp pond soils in Southern Thailand for cultivation of Mauritius grass (Brachiaria mutica). Environmental Gerochemistry and Health. 25:365-386.

Tripathi N.K., Annachchatre A. and Patil A.A. (2000) Role of remote sensing in environmental impact analysis of shrimp farming. In: Proceedings of the Map India 2000, New Delhi, India, April 10-11, pp. 14-16.

Weerakoon D.E.M. (2007) Towards sustainability of black tiger shrimp (Penaeus monodon) farming in Sri Lanka. Aquaculture Asia. 12:3-7.

Witteveldt J., Cifuentes C.C., Vlak J. M. and van Hulten M.C. (2004) Protection of Penaeus monodon against white spot syndrome virus by oral vaccination. Journal of Virology 78:2057-2061. 
Supplementary table S1: Carbon loss or gain induced by land cover/use conversion around Puttalam lagoon in 1992/1994-2012 in tC. M=mangrove; SF=shrimp farms; SP=salt pan; C=coconut plantations; other= other land-use; No change represents unchanged mangrove areas, included here to show amounts of carbon sequestered by untouched mangroves.

\begin{tabular}{|c|c|c|c|c|c|c|}
\hline & \multicolumn{3}{|c|}{ Carbon stocks lost } & \multicolumn{3}{|c|}{ Carbon stocks gained } \\
\hline & $\begin{array}{c}1992 / 1994- \\
2007 \\
\end{array}$ & $2007-12$ & $\begin{array}{c}1992 / 1994- \\
2012 \\
\end{array}$ & $\begin{array}{c}1992 / 1994- \\
2007 \\
\end{array}$ & $2007-12$ & $\begin{array}{c}1992 / 1994- \\
2012 \\
\end{array}$ \\
\hline $\mathrm{C} \rightarrow \mathrm{M}$ & 161.9 & 239.5 & 401.4 & & & \\
\hline $\mathrm{C} \rightarrow \mathrm{SF}$ & 852.6 & 1104.1 & 1956.7 & & & \\
\hline $\mathrm{C} \rightarrow \mathrm{SP}$ & 48.3 & 496.7 & 545 & & & \\
\hline $\mathrm{M} \rightarrow \mathrm{C}$ & 2017.8 & 62.7 & 2080.5 & & & \\
\hline $\mathrm{M} \rightarrow \mathrm{SF}$ & 161153.1 & 23600.3 & 184753.4 & & & \\
\hline $\mathrm{M} \rightarrow \mathrm{SP}$ & 979.4 & 626.3 & 1605.7 & & & \\
\hline $\mathrm{M} \rightarrow$ other & 12462.9 & 40772.8 & 53235.7 & & & \\
\hline $\mathrm{SF} \rightarrow \mathrm{C}$ & & & & 0.43 & 58 & 58.43 \\
\hline $\mathrm{SF} \rightarrow \mathrm{M}$ & & & & 6 & 21,5 & 27.5 \\
\hline $\mathrm{SP} \rightarrow \mathrm{M}$ & & & & 11 & 0.02 & 11.02 \\
\hline $\mathrm{SP} \rightarrow \mathrm{C}$ & & & & 0 & 5.6 & 5.6 \\
\hline $\begin{array}{l}\mathrm{M}-\text { no } \\
\text { change }\end{array}$ & & & & 44048.6 & 8843.7 & 52892.3 \\
\hline Total & 177676 & 66902.4 & 244578.4 & 44066 & 8928.8 & 52994.9 \\
\hline
\end{tabular}

